\title{
ANALYSIS OF IMPLEMENTATION OF MATERNITY PLANNING AND PREVENTION OF COMPLICATION (P4K) PROGRAM WITH STICKERS IN PURWAKARTA REGENCY 2017
}

\author{
Yunita Restu Safitri ${ }^{1}$, Pujiyanto ${ }^{2}$ \\ ${ }^{1}$ Health Policy and Administration, Faculty of Public Health, Universitas Indonesia, \\ Kampus Depok, Jawa Barat, 16425, Indonesia \\ ${ }^{2}$ Health Policy and Administration, Faculty of Public Health, Universitas Indonesia, \\ Kampus Depok, Jawa Barat, 16425, Indonesia
}

Email : yunita.restu.safitri@gmail.com

\begin{abstract}
Pregnant women are one of the risk groups that should be considered to receive particular attention. Maternal mortality is caused by direct and indirect causes, which generally can be identified in early pregnancy. The Ministry of Health has launched various programs to reduce maternal mortality. At the community level, since 2007, there has been a birth planning and prevention of complications $(\mathrm{P} 4 \mathrm{~K})$ program as a screening tool for pregnant women at risk by using stickers. The main point of this program is the active participation of families and communities to care for pregnant women in their environment. Purwakarta Regency, a region with uncomplicated geographical conditions, is supported by Health Human Resources (SDMKes) and Health facilities to do various programs in reducing the number of maternal deaths; one of them is P4K with stickers. In 2017, there were still 21 maternal deaths that should have been identified and referred to the hospital if the program was running well. The study aims to analyze the implementation of the P4K Sticker at the District Level. This research is qualitative research with in-depth interviewing techniques involving 12 informants and related documents, according to the theory of Van Meter and Van Horn policy implementation based on 6 (six) variables. This study found that the standard and policy objectives have not been fully achieved. There is still insufficient funding to support the program optimally. In terms of communication, there still a different understanding between the Health Office and Primary Healthcare Center. Despite there are still constraints on the number of human resources, the program's attitude is supportive. Economic and political situations are good, but social conditions are not supportive. The conclusion is that the program's implementation still has constraints in each variable. Existing program barriers can be overcome by optimizing inter-organizational communication, in this case, the District Health Office with Primary Healthcare Center, to have a common understanding regarding the implementation of Sticker P4K.
\end{abstract}

Keywords: policy analysis, policy implementation, pregnant women, delivery planning.

Abstrak. Ibu hamil merupakan salah satu kelompok berisiko yang harus mendapatkan perhatian khusus. Penyebab langsung dan tidak langsung kematian ibu pada umumnya bisa diidentifikasi sejak dini. Sejak tahun 2007 telah ada Program Perencanaan Persalinan dan Pencegahan Komplikasi (P4K) dengan fungsi menyaring ibu hamil yang berisiko dengan menggunakan alat bantu stiker. Dalam program ini ada partisipasi aktif keluarga dan masyarakat untuk peduli ibu hamil di lingkungannya. Kabupaten Purwakarta telah melaksanakan program P4K dengan stiker sejak tahun 2017. Hasilnya masih terjadi 21 kasus kematian ibu pada tahun 2017. Seharusnya jika program P4K dengan stiker berjalan dengan baik sudah dapat dilakukan identifikasi awal dan penatalaksanaan rujukan yang baik. Penelitian ini dimaksudkan untuk mengases bagaimana program P4K dengan stiker diimplementasikan. Analisis implementasi program P4K dilakukan berdasarkan teori implementasi kebijakan Van Meter dan Van Horn yang terdiri dari enam variabel. Penelitian dilakukan secara kualitatif dan pengumpulan data dengan teknik wawancara mendalam pada 12 informan dan telaah dokumen. Hasil penelitian menemukan bahwa standar dan sasaran kebijakan belum sepenuhnya tercapai. Sumber daya keuangan belum optimal dalam menunjang penyelenggaraan program. Dalam komunikasi antar organisasi masih ditemukan pemahaman yang berbeda antara Dinas Kesehatan dan Puskesmas sebagai pelaksana. Karakteristik pelaksana terkendala oleh jumlah SDM belum mencukupi namun sikap pelaksananya mendukung. Kondisi ekonomi dan politik baik namun kondisi sosial kurang mendukung. Sebagai kesimpulan implementasi program P4K memiliki kendala pada setiap variabel. Hambatan program yang ada bisa diatasi dengan mengoptimalkan komunikasi antar organisasi Dinas Kesehatan Kabupaten dan Puskesmas agar memiliki pemahaman yang sama terkait P4K dengan stiker.

Kata kunci: Kematian ibu, analisis kebijakan, implementasi kebijakan, perencanaan persalinan 


\section{INTRODUCTION}

The World Health Organization (WHO) defines maternal death as a condition of death in women of childbearing age 15-49 years who are pregnant, during childbirth, or postpartum (40 days after childbirth) either by direct or indirect causes. The condition is still counted regardless of the gestational age, fetus attachment location related to the pregnancy, or its management, unless caused by accident or suicide (Ministry of Health, 2013). Maternal death is still a major problem in the field of public health in Indonesia. According to the 2012 Indonesian Health Demographic Survey (IDHS) data, the maternal mortality rate (MMR) was 359 / 100,000 live births and decreased to 305 / 100,000 live births based on the 2015 SUPAS data. The causes of maternal death are divided into two, which are direct and indirect causes. Based on the percentage of maternal deaths, the most significant causes of direct causes are bleeding (28\%), eclampsia (24\%), infection (11\%), and others (IDHS, 2012). In addition, several factors influence the indirect causes of maternal death. From the 2010 Riskesdas data analysis, four factors are education, economic status, and the mother's desire to have children.

The government has accelerated the reduction of MMR through clinical and community arrangements. In 2007 the Ministry of Health launched a breakthrough Program for Childbirth Planning and Complications Prevention (P4K) with stickers. The P4K program aims to increase the coverage and quality of health services for pregnant women and newborns through increasing family and community participation in (i) planning safe delivery and (ii) preparing for complications and (iii) obstetric warning signs so that they become manageable more quickly. The output of the P4K program are (i) all pregnant women are registered, and their houses are affixed with stickers, (ii) standard ANC services, (iii) standard delivery services, (iv) standard postpartum services, (v) mothers and their families have a delivery plan including family planning, (vi) the family prepares the cost of delivery, (vii) community involvement such as the KIA care forum / pokja posyandu, (viii) contraception services, and (ix) collaboration between midwives, assistants primary healthcare centers, MCH care forums, traditional birth attendants and assistants labor. (Ministry of Health, 2010). Planning for childbirth is essential to reduce complications, and if they do occur, the mother can be immediately referred to advanced healthcare facilities.

The P4K program with stickers is implemented based on the Circular Letter from Minister of Health No. 295 of 2008 and Circular Letter from Minister of Home Affairs No. 441.7 / 1935.SJ in 2008 concerning the acceleration of the implementation of the Maternity Planning Program and the Prevention of Complications (P4K) (MOH, 2010). In 2019, all Puskesmas would have implemented the P4K Program orientation in their area, which is one of the targets of the Ministry of Health's Strategic Plan 2015-2019 (Ministry of Health, 2015). Although the P4K program with stickers has been implemented, it has not contributed significantly to reducing MMR.

Therefore, it is necessary to analyze the $\mathrm{P} 4 \mathrm{~K}$ program implementation policies with stickers. This study aims to measure the implementation of the $\mathrm{P} 4 \mathrm{~K}$ program with stickers based on six variables according to Van Meter and Van Horn, which are (1) policy standards and objectives, (2) resources, (3) communication between executor organizations, (4) executor characteristics, (5) ) the disposition of the executor, and (6) the social, economic and political conditions.

\section{METHOD}

This study uses a qualitative method to identify problems, analyze and compile recommendations for implementing the $\mathrm{P} 4 \mathrm{~K}$ program with stickers in Purwakarta Regency 2017. The data collection techniques are in-depth interviews and document review.

Informants are selected based on the principles of appropriateness and adequacy. Informants were selected with the criteria of involving in the $\mathrm{P} 4 \mathrm{~K}$ program with stickers in the Purwakarta Regency in 2017. Information gathering was considered complete after no new information was found from the informants. Research informants are divided into two, which are core informants and additional informants. Key informants are those who directly influence the implementation of the $\mathrm{P} 4 \mathrm{~K}$ program with stickers in Purwakarta District, which are:

1. The Head of the Purwakarta District Health Office,

2. The Head of the Public Health Division of the Purwakarta District Health Office,

3. The Head of the Family Health and Nutrition Section Purwakarta District Health Office,

4. Head of Health Promotion and Community Empowerment Section of Purwakarta District Health Office,

5. Two staff of the Family Health and Nutrition Section of the Purwakarta District Health Office and two coordinating midwives in charge of $\mathrm{P} 4 \mathrm{~K}$ with stickers.

Additional informants consisted of:

1. Director of Family Health, Ministry of Health,

2. Director of Health Promotion and Community Empowerment, Ministry of Health,

3. Head of Sub-Directorate for Maternal and Neonatal, Ministry of Health,

4. Two teams drafting $\mathrm{P} 4 \mathrm{~K}$ guidelines with stickers, and 
5. Two elected Village Heads for the working area of the Puskesmas.

Data collection by the document is reviewed by mapping the Purwakarta District Health Profile data for 2014, 2015, and 2016 to determine trends in maternal mortality in each area of the Primary Healthcare Center. Subsequently, two Primary Healthcare Centers with cases of maternal death were determined, and their locations represented urban and rural areas. After that, in-depth interviews were carried out starting from the central, district, program managers, and related crosssectoral levels in the field to see the flow of $\mathrm{P} 4 \mathrm{~K}$ program implementation with a sticker. The research instrument used was an interview guide containing open-ended questions to obtain in-depth information about the studied problems.

\section{RESULT}

\section{Policy Standards and Objectives}

According to the 2015-2019 family health strategic plan, one of the indicators related to the $\mathrm{P} 4 \mathrm{~K}$ program with stickers is the percentage of Puskesmas that conduct P4K orientation with stickers. All (100\%) Puskesmas in Purwakarta Regency have carried out the P4K program orientation with stickers. Key informants can explain what the $\mathrm{P} 4 \mathrm{~K}$ program indicators and objectives are with stickers. However, two midwives who carried out these activities said they had never seen and understood the indicators to assess an area/village that had carried out the $\mathrm{P} 4 \mathrm{~K}$ program with stickers. Program managers at the Primary healthcare center use indicators that all pregnant women who received stickers have entered the $\mathrm{P} 4 \mathrm{~K}$ implementation with stickers. For additional informants only from the Ministry of Health can explain the indicators and targets of the program in detail.

In the implementation at the Ministry of Health level, there is a routine 3 (three) monthly report by the District / City Health Office to the data manager at the Directorate of Family Health. Data were collected from all existing villages through the coordinating midwife to produce an indicator of the number of villages implementing the $\mathrm{P} 4 \mathrm{~K}$ program. The report results on the achievements of Purwakarta Regency all villages have carried out $\mathrm{P} 4 \mathrm{~K}$ orientation with stickers and have carried out the P4K program (100\%).

\section{Policy Resources}

Human resources for implementing the program already exist, but the distribution is not even. This situation is not a problem because the program's implementation complements each other between program managers. The number of staff for Maternal and Child Health at the Purwakarta District Health
Office is still less than one administrative staff. For Puskesmas, the number of human resources is sufficient, but it is not evenly distributed; some feel that it is lacking, and some others are sufficient. The interview results with the coordinating midwife showed that the P4K program had been implemented but was still limited to installing stickers.

In its implementation, the Coordinating Midwife is assisted by village midwives and health cadres. With the increased community participation, the health sector has also collaborated with cross-programs such as the Sub-District Office. One of the Puskesmas coordinator midwives' informants complained about the workload due to additional administrative and reporting activities, leaving midwives not having time to provide routine technical guidance to the field.

In 2017, the APBN funds available for the Purwakarta District Health Office were 550 million rupiahs. With the Child Health and Nutrition program, these funds were only used up to $19.35 \%$ or one-fifth of the budget. As a result, in that year, the program only focused on preventive activities, and for all promotional activities, many were postponed, so there were no funds to refresh the program in the last two years. There are no funding problems at the Primary Healthcare Center level because the $\mathrm{P} 4 \mathrm{~K}$ program with stickers was combined with the implementation of classes for pregnant women and other activities.

Activity incentives in the form of rewards and punishments are carried out simultaneously with maternal and child health activities. So far, the punishment is still in the form of a warning if it does not collect reports on time. However, specifically for the $\mathrm{P} 4 \mathrm{~K}$ program with stickers, there are no health workers who have been subject to punishment.

The availability of health service facility infrastructure and information systems to support the implementation of the $\mathrm{P} 4 \mathrm{~K}$ program with stickers in Purwakarta Regency, both at the Primary Healthcare Center and the Health Office, is sufficient. The health facilities in Purwakarta Regency consist of 12 health centers scattered in each sub-district and regional public hospitals. The location is also easy to reach by the community.

Socialization of the $\mathrm{P} 4 \mathrm{~K}$ program with stickers does not require separate information and scholarly communication media. All pregnant women who come to the health facility for a pregnancy check-up will be recorded as the first visit (K1). At that time, a Maternal and Child Health book (KIA book) will be given, in which there is a P4K sticker sheet that is equipped with an explanation of how to fill it. The number of $\mathrm{MCH}$ books and $\mathrm{P} 4 \mathrm{~K}$ stickers available is sufficient according to the target number of pregnant women.

Suppose during the first meeting pregnant women 
come alone. In that case, they will be reminded of the importance of involving their husbands or other family members who permanently live with the pregnant mother to participate in further examinations to prepare a birth plan. Thus, when an emergency occurs, there are still other family members to communicate. To explain the agreed delivery plan, it must fill in the delivery mandate known by three parties: themselves, family members, and midwives who provide services.

\section{Communication between Implementing Organizations}

The study results found differences between informants from the Health Office and across programs and sectors at the sub-district / primary healthcare center level. An informant from the Purwakarta Regency Health Office said the information related to the $\mathrm{P} 4 \mathrm{~K}$ program with stickers was clear enough. However, the implementation in the field/primary healthcare center, both cross-program and cross-sector, is still limited to the education of pregnant women and the filling and sticking of stickers only - the $\mathrm{MCH}$ forum as a forum for cross-program and cross-sector collaboration is not yet applicable. Regarding blood donation and village ambulances, the collection and use mechanism is still not understood. Apart from that, the funding is still too late, especially those involving non-governmental organizations.

All key informants understand the standard P4K program with stickers, both about the indicators that must be achieved and the planning process. However, health workers in the field still do not have the same understanding.

The Health Office informant said that at every opportunity, he conveyed the P4K policy with a sticker to program managers at the Puskesmas and across sectors and regularly held a program evaluation meeting every month. However, it turns out that the information received by end-users varies. No SOP document regulates the implementation of the $\mathrm{P} 4 \mathrm{~K}$ program with stickers.

\section{Executor Characteristics}

The management of the P4K with Stickers program in Purwakarta is still centered in Family Health Sector, especially the $\mathrm{MCH}$ and Nutrition Sections. This condition is in line with the $\mathrm{P} 4 \mathrm{~K}$ with stickers program executors implemented by KIA officers. Each related party knows the duties and responsibilities according to the applicable procedures. However, there are still obstacles in implementation, from internal aspects and from external to the organization and the community.

Relations between organizations across programs and sectors in implementing the $\mathrm{P} 4 \mathrm{~K}$ program with stickers are running well. The Health Office, Primary Healthcare Center, and their networks and across sectors have regular schedules of coordination meetings in the context of socialization, monitoringevaluation, and coaching.

\section{Executor's Disposition / Attitude}

In general, the executors are supportive of the implementation of the $\mathrm{P} 4 \mathrm{~K}$ program with stickers. Executor from the Purwakarta District Health Office and Primary Healthcare Center have tried their best to implement it consistently by preparing relevant resources, institutions, and programs. The executors have the same commitment to improving the quality of the implementation of activities. Even though the attitude of the executor is supportive, but the implementation of ideal services still cannot be provided because the executor has to exceed their capacity limit; over time, the quality of service decreases.

\section{Social, Economic, and Political Conditions}

Key and additional informants stated that at the district level, the factor that most influences policy is politics because each new leader is elected, influencing the policies taken and impacting the allocated budget. However, at the field/health center level, the socioeconomic conditions are more influential. The socioeconomic condition of the community makes people reluctant to have pregnancy and childbirth checks because of the high cost.

\section{DISCUSSION}

\section{Policy Standards and Objectives}

Even though all $\mathrm{P} 4 \mathrm{~K}$ programs have been announced, overall, the standards and policy targets regarding the implementation of $\mathrm{P} 4 \mathrm{~K}$ with stickers still encounter obstacles. District Health Offices and program managers at Primary Healthcare Center need to ensure that the coordinating midwife, village midwife, health cadres, and related cross-programs agree on the correct indicators, targets, and stages of activities. Therefore, creating suitable quality activities.

Informants from the Ministry of Health to the District Health Office have a good understanding of the program indicators. However, this level of good understanding has not yet reached the program managers in the field, which is the coordinating midwife at the Primary Healthcare Center and crosssectoral in the field such as village officials and heads of community associations (RW). As a result, program managers at the Primary Healthcare Center only record data according to the number of $\mathrm{K} 1$ according to the pregnant women who received the KIA book so that the implementation of $\mathrm{P} 4 \mathrm{~K}$ with stickers aimed at 
increasing family and community participation in welcoming pregnancies and births of babies safely and healthily has not been achieved.

Van Meter and Van Horn suggest that identifying performance indicators is a crucial stage in policy implementation. Policy standards and objectives form the basis for policymakers to engage with policy executors in the field. Indicators become the goals and tools for assessing policy executors on how much or how extent the objectives or policy objectives have been achieved. (Winarno 2012)

\section{Policy Resources}

In general, human resources to implement policies are sufficient but not evenly distributed. From the interview results, it was found that there were no problems related to the $\mathrm{P} 4 \mathrm{~K}$ program supporting facilities in the field. The system information facility also does not have a problem. The availability of an optimal information system is part of the facility resources requirements. The essence of the availability of IEC facilities is the understanding and communication skills of the executor to ensure that pregnant women are in a particular situation that requires special attention.

According to Van Meter Van Horn (Meter \& Horn 1975), policy resources deserve attention because they support the success of policy implementation. The resources referred to are facilities, funds, and other incentives/incentives that encourage effective policy implementation (Winarno 2016). Human resources are not only significant in terms of quantity but also the skills necessary to implement policies. The limited number of adequately trained policy executors will hinder policy implementation (Winarno 2012).

This condition is in line with what was conveyed by Van Meter and Van Horn. Successful implementation is implementing an organization's ability to do what they are expected to do. The ability to implement policies may be hampered by factors such as poorly trained staff and overwork (Winarno 2016)

In theory, providing an incentive system can be a form of resource optimization. This act is necessary to obtain maximum support from the executor. Providing incentives in various forms, such as personal interests (self-interest) or sanctions, are seen as improving and supporting the positive attitudes of policy executors (Yalia 2014). Other studies suggest that the incentive system does not always have to be in the form of money. High motivation, communication, empathy, and support can help increase the commitment of program personnel who are very instrumental in achieving the success of the immunization program. (Susyanty et al. 2014)
Conceptually, lack of resources will result in the ineffective implementation of policies. This condition is following the theory presented by Edwards (1980) in Nugroho (2017) that "lack of the resources necessary to carry out policies, implementation is likely to ineffective."

\section{Communication between Implementing Organizations}

Communication between implementing organizations in the $\mathrm{P} 4 \mathrm{~K}$ program with stickers in Purwakarta Regency has not been going well. In communication between implementing organizations, clarity is defined as the executors' understanding of the content of the policy (Yalia 2014). According to Van Meter and Van Horn (1975), successful policy implementation requires institutional mechanisms and procedures. It is intended that policymakers encourage policy executors to act consistently with the standards and policy objectives that have been set (Winarno 2016). Consistent implementing rules will not confuse the executors (Yalia 2014).

The clearer the SOP for implementing policies, the easier it is for policy executors to know, understand, and explore the results' substance (Said, La Ode Agus; Noor 2015). SOPs developed as an internal response to limited time and resources from policy executors and a desire to work in uniformity (Agustino 2008). SOPs can simplify the process of making decisions and adapt program responsibilities to existing resources and uniform actions of the executors so that it is possible to adapt or adjust to the demands of change (Yalia 2014).

\section{Implementing Characteristics}

Each P4K program implementing party already knows their duties and responsibilities to the applicable procedures. Relations between organizations across programs and sectors are also running well. With clarity of each program's duties and responsibilities, it is hoped to minimize the emergence of coordination obstacles with other institutions. The continuity of the organizational structure from the central to the lowest level (Primary Healthcare Center) is proven to make it easier for executors in communication, coordination, information delivery, monitoring evaluation, and guidance in implementing the $\mathrm{P} 4 \mathrm{~K}$ program with stickers.

Van Meter and Van Horn (1975) stated that the relationship between organizations is one aspect that influences an organization in implementing policy. Relationships between organizations are defined as the level of "open" communication, a free horizontal and vertical communication network, and a relatively high level of freedom in communication with individuals outside the organization (Winarno 2016). 


\section{Executor's Disposition / Attitude}

In summary, the attitude of $\mathrm{P} 4 \mathrm{~K}$ program executors is only doing services to abort obligations. Of course, this will have an impact on service quality. According to Van Meter and Van Horn (1975), the disposition/attitude of the executor plays a significant role. Successful implementation of policies must be followed by the awareness and understanding of the policy standards and objectives. The implementation trend's direction can be seen from the acceptance or rejection of the policy standards and objectives. Acceptance of policy standards and targets that policy executors widely accept will drive the success of policy implementation. (Winarno 2016)

\section{Social, Economic, and Political Conditions}

At the district health office level, the implementation of the $\mathrm{P} 4 \mathrm{~K}$ program policy is influenced by political conditions, so it is necessary to increase advocacy in the executive and legislative bodies that can allocate budgets. Meanwhile, at the community level/field, the social and economic conditions are more influential in the success of the P4K program. As Van Meter and Van Horn (1975) stated, the social, economic, and political conditions in society are essential factors in the success of policy implementation (Winarno 2016).

\section{CONCLUSION}

Executors of the $\mathrm{P} 4 \mathrm{~K}$ program with stickers in the field/Primary Healthcare Center do not understand the standards and policy targets. The Primary Healthcare Center coordinating midwife does not yet know the indicators used in assessing the program. Health resources for implementing $\mathrm{P} 4 \mathrm{~K}$ with stickers are pretty good, but the budget amount is insufficient; even in 2017 , there was no budget from the district.

Communication between implementing organizations in the $\mathrm{P} 4 \mathrm{~K}$ program has not gone well. Meanwhile, the characteristics of the executors and the attitudes/dispositions of the executors in implementing the $\mathrm{P} 4 \mathrm{~K}$ program with stickers are good enough. The political conditions were quite supportive, while the socio-economic conditions of the community did not support the implementation of the $\mathrm{P} 4 \mathrm{~K}$ program.

\section{SUGGESTION}

The P4K program should be socialized across sectors and programs at the central, provincial, and district/city levels. At the sub-district/Primary Healthcare Centers level, the P4K program orientation should be held to the stakeholders on all maternal and infant health, including community and religious leaders, PKK activating teams, midwives, health cadres, and village/community officials.

\section{REFERENCES}

Alkema, Leontine et.al. 2014. Global causes of maternal death: a WHO systematic analysis, The Lancet Global Health Volume 2, No. 6, e323e333, June 2014, http://www.thelancet.com/journals/langlo/article/ PIIS2214-109X(14)70227-X/fulltextAnderson, J. E. (2011). Public policymaking : an introduction. Wadsworth/Cengage Learning. Retrieved from https://books.google.co.id/books/about/Public_Po licymaking.html?id=A3phpKTD1pYC\&redir_esc $=\mathrm{y}$

Ayuningtyas, D. (2014). Kebijakan Kesehatan Prinsip an Praktik (1st ed.). Jakarta: Rajawali Press.

Azwar, Azrul. 2010. Pengantar Administrasi Kesehatan. III. Jakarta: Bina Rupa Aksara.

Badan Pusat Statistik (BPS) Jawa Barat. 2010. Susesda 2009 Jawa Barat.

Balitbangkes. 1993. Laporan Nasional 1992 Survei Demografi Kesehatan Indonesia (SDKI) 1992.

. 1996. Laporan Nasional 1995 Survei Demografi Kesehatan Indonesia (SDKI) 1995.

. 2001. Laporan Nasional 2000 Survei Demografi Kesehatan Indonesia (SDKI) 2000.

. 2008. Laporan Nasional 2007 Survei Demografi Kesehatan Indonesia (SDKI) 2007.

. 2013. Laporan Nasional 2012 Survei Demografi Kesehatan Indonesia (SDKI) 2012.

Balitbangkes. 2008. Laporan Nasional 2007 Riset Kesehatan Dasar (RISKESDAS) 2007.

Balitbangkes. 2014. Laporan Nasional 2013 Riset Kesehatan Dasar (RISKESDAS) 2013.

Balitbangkes. 2018. Laporan Nasional 2013 Riset Kesehatan Dasar (RISKESDAS) 2018.

Balitbangkes. 2017. Laporan Nasional 2017 Survei Kesehatan Nasional (Sirkesnas) 2016.

Bappenas. 2009. Perhitungan Pembiayaan dalam Pencapaian Millenium Development Goals, Jakarta.

BKKBN, BPS, and Kemenkes. 2013. Survei Demografi Dan Kesehatan Indonesia 2012. Jakarta.

Buse, K., Mays, N., \& Walt, G. (2012). Making health policy. Open University Press. Retrieved from https://books.google.co.id/books/about/Making Health Policy.html?id=LL1M41OzXtwC\&redir esc $=y$

Creswell, J. W. (2009). Research design: Qualitative, quantitative, and mixed methods approaches (3rd ed.). Thousand Oaks, CA: Sage. 
Departemen Kesehatan. 2008. Pedoman Penyelenggaraan Pelayanan Obstetri Neonatal Emergensi Komprehensif (PONEK) 24 Jam di Rumah Sakit. Jakarta.

Dinas Kesehatan Kabupaten Purwakarta. (2014). Profil Kesehatan Kabupaten Purwakarta

Kesehatan Kabupaten Purwakarta

(2015). Profil

(2016). Profil

Kesehatan Kabupaten Purwakarta Dwijayanti, Putri. 2013. "Analisis Implementasi Program Perencanaan Persalinan Dan Pencegahan Komplikasi (P4k) Oleh Bidan Desa Di Kabupaten Demak.” Jurnal Kesehatan Masyarakat Volume 2, Nomor $\quad 1$ Tahun 2013. http://ejournals1.undip.ac.id/index.php/jkm

Grindle, M. S., \& Smith, B. C. (1982). Politics and policy implementation in the third world. Public Administration and Development (Vol. 2). John Wiley \& Sons, Ltd. https://doi.org/10.1002/pad.4230020308

Kementerian Kesehatan RI. (2010). Program Perencanaan Persalinan dan Pencegahan Komplikasi (P4K) dengan Stiker. Jakarta.

Kementerian Kesehatan RI. (2013). Rencana Aksi Nasional Percapatan Penurunan Angka Kematian Ibu. Jakarta.

Kementerian Kesehatan RI. (2013). Pedoman Penyelenggaraan Puskesmas Mampu PONED. Jakarta

Kementerian Kesehatan RI. (2015). Rencana Strategis Kementerian Kesehatan Tahun 2015-2019 (Keputusan Menteri Kesehatan Republik Indonesia Nomor HK.02.02/MENKES/52/2015). Jakarta.

Kementerian Kesehatan. 2016. Buku Kesehatan Ibu dan Anak. Jakarta

Lawn, Yoy E, et al. 2007. Continuum of care for maternal, newborn, and child health:

from slogan to service delivery. Lancet 2007; 370: 1358-69.

http://www.who.int/pmnch/topics/20071003lance t.pdf

Malande et al. 2016. Birth Preparedness, Complication Readiness and Male Partner Involvement for Obstetric Emergencies in Rural Ruwanda. The Pan African Medical Journal. https://www.ncbi.nlm.nih.gov/pmc/articles/PMC5 325493/

Martha., \& Kresno. (2016). Metodologi Penelitian Kualitatif untuk Bidang Kesehatan. Jakarta: PT Raja Grafindo Persada.

Meter, D.S. Van \& Horn, C.E. Van, 1975. The Policy Implementation Process. Administration \& Society, 6(4), pp.445-488. Available at: https://doi.org/10.1177/009539977500600404.

Nugroho, R. (2017). Public Policy (enam). Jakarta: PT Elex Media Komputindo.
Notoatmodjo, Soekidjo. 2010. Metode Penelitian Kesehatan. Jakarta: PT Rineka Cipta.

Prabandari, Yunilla. Diffah Hanim, Risya Cilmiaty AR, dan Dono Indarto. 2016. "Hubungan Kurang Energi Kronik Dan Anemia Pada Ibu Hamil Dengan Status Gizi Bayi Usia 6-12 Bulan Di Kabupaten Boyolali

(Correlation Chronic Energy Deficiency And Anemia During Pregnancy With Nutritional Status Of Infant 6-12 Months In Boyolali Regency)". Jurnal Litbangkes. 2016. 